\title{
Desempenho das Exportações da Indústria Intensiva em P\&D: comparação entre o Brasil e países selecionados no período 1994-2005*
}

\author{
Clésio Lourenço Xavier \\ Ana Paula Macedo Avellar \\ Samantha Ferreira e Cunha
}

Instituto de Economia - Universidade Federal de Uberlândia

\section{Resumo}

O artigo trata da inserção exportadora de produtos de alta intensidade tecnológica do Brasil entre 1994 e 2005, comparando tal inserção externa com a experiência de países desenvolvidos (EUA e Japão) e países em desenvolvimento (Coréia do Sul e México). Para tanto, o artigo utiliza a metodologia desenvolvida por Pavitt (1984) para classificar as exportações segundo as capacidades tecnológicas dos setores e respectivos encadeamentos intra e interindustrial e desempenho exportador. Os resultados encontrados apontam que os países em desenvolvimento apresentaram um crescimento das exportaçōes da "indústria intensiva em P\&D", todavia, seu market-share ainda é muito baixo vis-à-vis a experiência das economias desenvolvidas.

\footnotetext{
* Os autores agradecem as sugestões e recomendações dos pareceristas anônimos, responsabilizando-se, como de praxe, pelos erros e omissões.
} 
Palavras-Chave | Exportações; Tecnologia; Brasil

Códigos JEL | F14

\begin{abstract}
The article investigates the export insertion of Brazilian high technological intensity products between 1994 to 2005 by comparing such international insertion with the experience of both developed (USA and Japan) and developing countries (South Korea and Mexico). The methodology developed by Pavitt (1984) is applied for classifying exports by sectors according to their technological capacity, concatenations intra and interindustry and export performance. The results show that high-tech exports increased in developing countries, but their market-share is very low when compared to the experience of developed economies.
\end{abstract}

KEYwords | Exports; Technology and Brazil

JEL-Codes $\mid$ F14

\title{
1. Introdução
}

O objetivo do presente artigo é analisar o desempenho das exportações brasileiras em setores de alta tecnologia à luz do debate sobre a importância da tecnologia como elemento condicionante da inserção externa de um país em desenvolvimento. Em outros termos, verificar-se-á se ocorreu uma mudança da composição setorial em direção aos setores de alta intensidade tecnológica do Brasil, comparando-a com a experiência recente (1994-2005) dos países desenvolvidos e países em desenvolvimento selecionados. 
Diante disso, a primeira seção trata da evolução do debate sobre os padrões de especialização, descrevendo sucintamente as diferentes abordagens na literatura, que envolvem a interação entre tecnologia e comércio exterior. O conceito de "padrão de especialização comercial" contemplado aqui se refere à estrutura setorial das exportações de um país, dada a composição setorial de uma determinada zona de referência geográfica, nesse caso, o artigo capta a evolução do mercado mundial. A segunda seção descreve os procedimentos metodológicos utilizados, bem como a tipologia construída por Pavitt em seu seminal artigo de 1984. A terceira seção apresenta os resultados obtidos da composição setorial das exportações para os países selecionados em dois subperíodos: 1994-1998 e 2001-2005. A última seção trata das considerações finais.

\section{Especialização comercial e tecnologia}

A evolução da teoria do comércio internacional apresenta diferentes formas de tratamento da inovação tecnológica, desde modelos clássicos que se preocupam exclusivamente com conceito de produtividade, minimizando o papel da tecnologia, até abordagens evolucionistas que consideram a alta importância da tecnologia como determinante dos padrões de especialização comercial.

No modelo ricardiano clássico, pode-se localizar em quais setores os países têm vantagens comparativas a partir das diferenças internacionais de produtividade, as quais poderão transformar-se ou não em vantagens absolutas, dependendo das diferenças nas taxas de salários e nas taxas de câmbio. Mas não se pode determinar a composição desses setores nos fluxos comerciais, para tanto se fazendo necessária a determinação da curva de demanda internacional.

Nessa interpretação, os diferenciais internacionais de produtividade constituem-se em um primeiro elemento a ser destacado como determinante da especialização internacional, ainda que não se possa definir sua composição setorial. Na verdade, a especialização ricardiana é sempre uma especialização setorialmente específica (produtos têxteis ou produtos farmacêuticos) determinada pelas vantagens comparativas de acordo com as taxas de crescimento das produtividades setoriais, diferentemente da especialização smithiana, em 
que o que importa é o grau de especialização determinado pelas economias de escala, desconsiderando-se a especificidade setorial (Dowrick, 1997).

Nessa perspectiva clássica, a exportação de produtos de elevado conteúdo tecnológico é diluída e minimizada, e o que importa são os diferenciais de produtividade intersetoriais, ao invés da intensidade tecnológica dos produtos.

Posteriormente, em Dornbusch, Fischer e Samuelson (1977), uma das formas de resolução dessa indeterminação do modelo ricardiano ocorreu através da utilização de um modelo contínuo de bens, em que se adotou a hipótese de homoteticidade das funções de demanda (funções que guardam as propriedades das funções homogêneas, entre as quais a de que as taxas marginais de substituição entre os produtos não mudam, diante de variações em seus níveis absolutos, caso se mantenham os preços relativos). Com isso, a parcela da renda gasta em cada um dos bens é constante, mesmo que cresça ou decresça a renda, desaparecendo as diferenças nas elasticidades-renda entre os bens e, por conseguinte, o problema da composição setorial.

No modelo convencional de Heckscher-Ohlin, é fundamental a presença das suposições de que a tecnologia é idêntica em todos os países - seja porque é um bem público, ou porque pode ser adquirida a um custo acessível - e de que as curvas de indiferenças são similares entre os parceiros comerciais, porque, dada uma mesma inclinação dos termos de troca (preços relativos internacionais), o padrão de especialização dos países ocorrerá naqueles produtos e/ou setores cuja produção seja mais intensiva no fator de produção localmente abundante, em termos relativos.

Um mecanismo central nesse modelo Heckscher-Ohlin de comércio internacional é a existência de flexibilidade intersetoriais rápidas o suficiente para compensar os ajustes intra-setoriais decorrentes da intensificação dos fluxos comerciais. Por isso, economias abertas poderiam obter ganhos líquidos em termos de produtividade e bem-estar em relação à autarquia, sem perda de emprego de qualquer um de seus fatores.

Em conformidade com esses supostos básicos, as implicaçōes da especialização comercial ocorreriam através da realocação de recursos produtivos, de acordo com as respectivas vantagens comparativas, aumentando a produtividade total, diminuindo os preços relativos dos bens importados e provocando uma redistribuição de renda favorável aos setores que utilizam mais 
intensivamente o fator de produção abundante. Esse efeito ficou conhecido na literatura de comércio internacional a partir do teorema de Stolper-Samuelson, o qual mostra que "[...] os preços dos fatores são dependentes do preço das mercadorias que produzem" (Gonçalves et al., 1998:26).

Dessa forma, também na interpretação de Heckscher-Ohlin, novamente a intensidade tecnológica dos produtos não importa na explicação dos fluxos comerciais, na medida em que a tecnologia é um bem livre ou facilmente imitável a curto prazo a um custo não-significativo.

As "novas" teorias do comércio internacional originaram-se a partir de uma revisão parcial do modelo Heckscher-Ohlin - no qual os fluxos comerciais são mais intensos entre os países que possuem diferenças significativas nas dotações de fatores -, diante da constatação paradoxal e empírica de que os fluxos comerciais são mais expressivos entre países desenvolvidos, ou seja, economias que possuem dotações de fatores similares (Dosi, Pavitt \& Soete, 1990).

Em outros termos, a existência de intensos fluxos comerciais intra-setoriais entre países desenvolvidos representou um fato estilizado suficientemente forte, indicando a necessidade de incorporação da complementaridade entre as estruturas produtivas dos países na explicação dos respectivos padrões de especialização. Tal revisão teórica foi feita a partir da incorporação dos supostos da teoria da concorrência imperfeita como base para uma teoria do comércio:

- as economias de escala externas à firma e internas à indústria podem implicar ganhos líquidos na situação de abertura comercial ainda que a preços de equilíbrio mais elevados;

- a diferenciação do produto com livre entrada nos mercados também é incorporada. A abertura comercial permitiria aos consumidores dos países envolvidos se defrontarem com uma variedade maior de produtos e as firmas com níveis de demanda superiores em relação à situação de "autarquia".

Essa possibilidade da incorporação da concorrência monopolística preencheu a inadequação dos modelos Heckscher-Ohlin na explicação dos padrões 
de especialização dos países, resolvendo o paradoxo, na medida em que os fluxos comerciais seriam mais intensos entre países desenvolvidos devido à similaridade de seus padrōes de demanda. Isto é, nesses países a produção reagiria à proximidade de seus padrôes de demanda com um maior fluxo comercial intra-setorial (Gonçalves et al., 1998:29-37).

Note que nessa abordagem de concorrência imperfeita reaparece a indeterminação presente no modelo ricardiano clássico, pois que a diferenciação de produto é incorporada a partir da hipótese de que todos os consumidores preferem uma grande variedade de produtos simétricos (forma funcional de Spence-Dixit-Stiglitz). Entretanto, tal variedade de produtos não é infinita como no modelo contínuo de bens de Dornbusch, Fischer e Samuelson (1977), porque é limitada pela existência de elevados custos fixos. Ou seja, existem economias de escala associadas aos custos fixos, as quais representam a existência de barreiras à entrada.

De acordo com Krugman (1989:1.217-1.218), nos modelos de comércio com concorrência imperfeita determina-se apenas o número de bens que é produzido, mas não se pode determinar quais bens serão produzidos devido à hipótese da simetria existente entre os bens. Vale dizer, o padrão de especialização novamente é indeterminado em função da presença de economias de escala.

De outro lado, os fluxos comerciais entre países desenvolvidos e países subdesenvolvidos - o comércio Norte-Sul - continuariam seguindo o modelo clássico Heckscher-Ohlin, através das diferentes dotações de fatores. Dessa forma, o comércio Norte-Sul seria constituído predominantemente de fluxos intersetoriais e não intra-setoriais.

Portanto, na aplicação dos modelos de concorrência imperfeita, não existiria lugar para a incorporação de casos intermediários de países que possuem graus elevados de articulação intra-industrial, como é o caso dos países em desenvolvimento (Canuto, 1994).

Apesar dessa restrição de não considerar os casos intermediários, as "novas" teorias do comércio internacional possibilitaram o reconhecimento da existência de externalidades e spill-overs intersetoriais, permitindo sua incorporação na formulação de políticas comerciais ativas, visando ao aumento do nível de produto das economias. 
Outra safra de modelos - denominados de modelos de hiatos tecnológicos - incorpora as diferenças tecnológicas entre países e suas implicações num arcabouço de equilíbrio geral: a abordagem dos ciclos do produto e sua relação com o comércio exterior, explorada nos conhecidos trabalhos de Posner (1961) ${ }^{1}$ e Vernon (1966), recebeu um tratamento formal simplificado em Krugman (1979), em que as diferenças tecnológicas Norte-Sul são mantidas através de taxas constantes de inovação no Norte e taxas de imitação no Sul, com uma certa defasagem temporal.

Dadas as diferenças de taxas de salário e câmbio entre o Norte e o Sul, as alteraçôes constantes dos coeficientes fixos no Norte e o aprendizado defasado do Sul permitiriam a manutenção da posição dos países do Norte e do Sul no comércio internacional. Caso contrário, se as taxas de inovação forem decrescentes no Norte, o padrão de especialização voltaria a ser determinado fatorialmente, dependendo da disponibilidade de mão-de-obra e de recursos naturais, bem como de estoques acumulados de capital. Portanto, nessa abordagem de hiatos tecnológicos, o padrão de especialização é parcialmente fixado de acordo com as capacidades de inovação no Norte e com as capacidades de imitação do Sul.

Um modelo mais geral de hiatos tecnológicos foi desenvolvido por Cimoli (1988), o qual considera que o padrão de especialização é flexível de acordo com a interação entre as variáveis "taxa de crescimento da produtividade", taxa de salários e efeitos das mudanças do padrão de especialização sobre as demandas por importações e exportações. Nesse modelo, além dos fatores tecnológicos incorporados por Krugman (1979), outras três variáveis são fundamentais, a saber: em primeiro lugar, as diferenças nas elasticidades-renda, permitindo a incorporação no modelo dos fatores de demanda; em segundo lugar, com a distinção entre mercadorias ricardianas - cuja especialização é determinada fatorialmente - e mercadorias inovativas, introduz a especificidade setorial na determinação dos padrões de especialização. Por último, incorpora-se também a variabilidade dos próprios padrões de especialização em função de alterações na taxa real de câmbio. 
Seguindo a mesma linha dos trabalhos de Posner (1961), Freeman (1968) corrobora com a hipótese em que o hiato tecnológico, entre países inovadores e imitadores, pode apresentar longa duração temporal. Ele demonstra empiricamente essa afirmação com um estudo sobre o setor de bens de capital eletrônicos nos Estados Unidos, identificando que a liderança exportadora desse setor no país está fortemente relacionada com o alto grau de desenvolvimento tecnológico. No entanto, ao mesmo tempo, esse autor admite a limitação do argumento considerando a dificuldade de generalização do comportamento de um único setor como o padrão do comércio internacional.

Finalmente, a literatura evolucionária demonstra a importância da tecnologia enquanto determinante da estabilidade dos padrões de especialização. O ponto de partida é o reconhecimento da natureza tácita e específica dos atributos tecnológicos, os quais são extensivamente incorporados em pessoas, rotinas e instituições (Canuto, 1995). Mediante tais suposições, a mudança tecnológica das empresas é, na verdade, uma mudança técnica envolvendo um processo de busca a partir do estoque de conhecimento existente nessas empresas e das externalidades públicas e privadas. Com isso, a mudança tecnológica é um processo de aprendizado cumulativo que condiciona e restringe as trajetórias das empresas e países na busca por ampliação de market-shares no comércio internacional (Dosi, Pavitt \& Soete, 1990). Por conseqüência, para a abordagem evolucionária a especialização do comércio apresenta relativa estabilidade, pois a capacidade de aprendizado dos agentes é limitada e o processo de inovação tecnológica está envolvido por um forte ambiente de incerteza (Laursen \& Meliciani, 1999:5).

À luz dessa discussão, pode-se evidenciar um aumento expressivo na importância da tecnologia enquanto elemento determinante dos padrões de especialização comercial de diversos países. Essa realidade se vem confirmando, em certa medida, na forma de inserção dos países em desenvolvimento na dinâmica do comércio internacional.

Segundo Mani (2000), a participação dos países em desenvolvimento no total das exportaçôes vem aumentando desde fins da década de 1980, representando cerca de três quartos do total exportado por esses países. Essa participação salta de aproximadamente 7,6\%, em 1988, para 17,5\% em 1998 (Mani, 2000:11). 
Ressalta-se também que a estrutura dessas exportações está composta por produtos de maior intensidade tecnológica, como o setor de máquinas e equipamentos. Para ilustrar esse fato pode-se observar que esse setor representava para os países em desenvolvimento $39 \%$ da pauta de exportações em 1988, atingindo, em 1998, o percentual de 52\%.

No entanto, esse mesmo autor identifica o risco de se analisar esse crescimento como um fenômeno geral dos países em desenvolvimento, argumentando sobre a presença de concentração da exportação de produtos manufaturados de maior intensidade tecnológica em um número restrito de países, destacando-se como os maiores exportadores desses produtos a China, a Coréia e Cingapura em 1997; o Brasil ocupa, nessa classificação, a sétima posição e a Índia se destaca como um dos principais exportadores de software, apresentando uma taxa de crescimento anual das exportaçôes de 50\% nos dez anos entre 1988 e 1998.

As mudanças observadas no mercado internacional com a ampliação da participação dos países em desenvolvimento nas exportaçōes de manufaturas foram acompanhadas por um crescimento expressivo dos fluxos de investimento direto externo (IDE) mundiais. A explicação para essas mudanças está relacionada às políticas de abertura econômica e financeira adotadas pelos países em desenvolvimento, com o relaxamento das restrições sobre os fluxos de investimento externo. Diante da idéia de um novo paradigma de crescimento econômico orientado para as exportações e "puxado" pelo IDE, as multinacionais têm um papel cada vez maior no desenvolvimento das economias.

Segundo a literatura evolucionária, o processo de importar uma nova tecnologia é custoso, de longa duração, de risco considerável e imprevisível quanto aos resultados, uma vez que a nova tecnologia envolve elementos tácitos que devem ser dominados. Nesse contexto, os fluxos de IDE constituem um importante canal para acessar novas tecnologias. As políticas de atração de IDE, de forma seletiva, podem contribuir para a superação das falhas de mercado relacionadas ao processo de aquisição de tecnologia pelos países em desenvolvimento (Lall, 2000).

Assim, o presente trabalho pretende avançar nessa problematização desenvolvendo uma avaliação empírica sobre o desempenho e o padrão de especialização das exportações brasileiras de produtos de maior intensidade 
tecnológica no período recente, comparando-as com as exportações de outros países desenvolvidos e em desenvolvimento.

\section{Procedimentos metodológicos}

Para a classificação das exportações de setores industriais com base em parâmetros tecnológicos, adotou-se como critério de agregação dos dados a tipologia desenvolvida por Pavitt (1984)² e Guerrieri (1994).

Esses autores formularam uma taxonomia das fontes, usos e mecanismos de geração de novas tecnologias, considerando a natureza abrangente e cumulativa da mudança tecnológica e da mudança técnica. Vale dizer, nessa taxonomia proposta a mudança tecnológica não se restringe apenas à intensidade fatorial ou à morfologia setorial, mas busca incorporar sobretudo as capacidades tecnológicas, as relaçôes de encadeamento intra e interindustrial e o desempenho no comércio internacional.

Por outro lado, isso indica, também, a cautela que se deve ter na utilização dessa taxonomia, porque um mesmo produto pode ser fabricado com tecnologias e com intensidades fatoriais distintas do padrão internacional. Um país que tem um elevado market-share em produtos de informática (intensivos em P\&D) não tem, necessariamente, competitividade em todas as etapas de desenvolvimento desses produtos (design, processo e mercado); no mesmo sentido, o sistema de produção de um produto pode estar concentrado apenas nas etapas a jusante de fabricação do produto (ao estilo das maquiladoras do norte do México), aproveitando-se apenas dos diferencias do custo de mão-de-obra.

Diante dessas ressalvas, o critério de agregação permite distinguir os seguintes grupos de empresas/indústrias:

a) produtos primários: agrícolas, minerais e energéticos;

b) indústria intensiva em recursos naturais: indústria agroalimentar, indústria intensiva em outros recursos agrícolas, indústria intensiva em recursos minerais e indústria intensiva em recursos energéticos. A principal caracte-

2 Bell e Pavitt (1993) avançam nessa taxonomia criando mais uma categoria de setor: intensivo em informação (information-intensive), cujas inovações são incrementais e o acúmulo de conhecimento se dá pela informação tecnológica. Exemplos dessa categoria encontram-se na indústria de serviços. Porém, considerando que a base de dados utilizada no presente artigo fornece informações somente por produto, a análise do presente artigo será pautada na taxonomia original apresentada no clássico artigo de Pavitt (1984). 
rística desse grupo é a existência de uma oferta elástica de matéria-prima como determinante das "vantagens comparativas" de um país ou de uma região;

c) induistria intensiva em trabalho (ou tradicionais): em que estão concentrados os mais tradicionais bens industriais de consumo não-duráveis como têxteis, confecções, couro e calçados, cerâmica, editorial e gráfico, produtos básicos de metais, entre outros. O grupo se caracteriza pelo fato de que o preço é o principal fator competitivo, nesse sentido, a escolha das trajetórias tecnológicas está relacionada à capacidade das inovações de processo, originadas nos setores fornecedores de equipamentos e materiais, de minimizar os custos.

Esses dois grupos anteriores se caracterizam pelo fato de serem apenas absorvedores líquidos dos processos de inovação simplesmente porque não geram novas tecnologias, mas apenas as adquire através da compra de equipamentos e insumos intermediários dos setores intensivos em escala ou intensivos em P\&D.

d) indústria intensiva em escala: inclui a indústria automobilística, a indústria siderúrgica e os bens eletrônicos de consumo. A presença de grandes empresas oligopólicas com elevada intensidade de capital, amplas economias de escala de processo, learning e organizacionais, bem como uma elevada complexidade nas atividades de engenharia, caracterizam esse grupo;

e) fornecedores especializados: inclui bens de capital sob encomenda e equipamentos de engenharia e são caracterizados pela elevada obtenção de economias de escopo, alta diversificação da oferta geralmente concentrada em empresas de médio porte, mas com uma notável capacidade de inovação de produto. Em sua maioria são empresas que desenvolvem estreito relacionamento com os usuários, com alta capacitação interna e domínio específico da tecnologia de projeto e engenharia;

f) indústria intensiva em $P \& D$ : faz parte desse grupo os setores de química fina (produtos farmacêuticos, entre outros), componentes eletrônicos, telecomunicaçôes e indústria aeroespacial, os quais são todos caracterizados por atividades inovativas diretamente relacionadas com elevados 


\section{QUADRO 1}

Tipologia Pavitt para exportações

\begin{tabular}{lll}
\hline Código & Classificação (Pavitt) \\
110 & Produtos primários agrícolas \\
120 & Produtos primários minerais \\
130 & Produtos primários energéticos \\
211 & Indústria agroalimentar \\
212 & Indústria intensiva em outros recursos agrícolas \\
213 & Indústria intensiva em recursos minerais \\
221 & Indústria intensiva em recursos energéticos \\
222 & Indústria intensiva em trabalho \\
223 & Indústria intensiva em escala \\
224 & Fornecedores especializados \\
\hline
\end{tabular}

Fonte: elaboração própria, a partir de Pavitt (1984).

gastos em $\mathrm{P} \& \mathrm{D}$, tendo suas inovações de produto um alto poder de difusão sobre o conjunto do sistema econômico.

O "tradutor" dos dados utilizado permitiu a agregação dos 258 grupos setoriais - em nível de 3 dígitos na classificação SITC (Standard International Trade Clasification) da ONU (Organização das Nações Unidas) - em apenas 11 subgrupos para as exportações mundiais.

Este trabalho tem como origem um "tradutor" utilizado em uma aplicação recente dessa mesma tipologia, o qual pode ser encontrado em Laplane et al. (2001).

É importante ressaltar que tal tradutor permitiu a agregação dos dados SITC (3 dígitos) apenas para a revisão 3, o que impossibilita a utilização de tal procedimento para séries estatísticas mais antigas, vale dizer anos 80 e 70, a menos que se utilize um outro tradutor da revisão 3 para a revisão 2 . Por conseguinte, o período de cobertura dos dados desenvolvidos neste 
trabalho restringiu-se apenas aos anos selecionados da década de 1990 e 20012005, para os quais existem dados disponíveis imediatamente. Para os anos de 1994-1998, a fonte de dados foi o CD-ROM PC-TAS - Trade Analysis System 1994-1998. Já para os anos de 2001-2005, foi utilizada a base de dados do INTRACEN (International Trade Centre) da UNCTAD/WTO (United Nation Conference for Trade and Development/World Trade Organization) para o período 2001-2005.

Finalmente, duas observações se fazem necessárias: em primeiro lugar, três grupos setoriais da revisão 3, sejam eles "Gás de carvão/Gás de água/etc." (SITC 345), "Pacotes postais não-classificados" (SITC 911) e "Transações especiais não-especificadas” (SITC 931), foram excluídos da agregação realizada neste trabalho pela simples impossibilidade de classificá-los adequadamente; em segundo lugar, todos os campos em que se encontravam a expressão \#N/D (não-disponível) foram substituídos por um valor nulo, a fim de viabilizar o somatório e a agregação proposta. Vale mencionar que a representatividade dos setores excluídos da agregação é muito baixa, apresentando uma participação relativa ao longo dos países da amostra, que variou de $0 \%$ a 4,2\% nos qüinqüênios selecionados (ver Tabela 1 da seção 4).

À luz dessa discussão, o presente artigo irá desenvolver na próxima seção um estudo empírico sobre o desempenho da composição setorial das exportações brasileiras, com ênfase na participação dos setores de alta intensidade tecnológica.

\section{Composição das exportações de países selecionados segundo intensidade tecnológica}

As informações empíricas a seguir foram elaboradas a partir dos dados brutos de exportação para os países selecionados (Brasil, México, Coréia, EUA e Japão), abrangendo os quinquênios 1994-1998 e 2001-2005. Os setores de exportação dos países foram classificados seguindo a metodologia Pavitt, reduzindo os grupos setoriais do comércio internacional em nível de 3 dígitos na classificação SITC para 11 subgrupos, com base em parâmetros tecnológicos. A escolha dos países leva em conta dois casos de países em desenvolvimento que fazem parte do grupo das economias em desenvolvimento mais 
avançadas (grupo D-7 da UNCTAD ${ }^{3}$ ), sendo uma experiência latino-americana (México) e outra experiência asiática (Coréia do Sul) e dois casos de países desenvolvidos (EUA e Japão), que se destacam nas exportações de produtos de alta intensidade tecnológica.

Um panorama geral da inserção externa e da composição setorial do Brasil e de mais quatro países selecionados (EUA, Japão, Coréia do Sul e México) no período recente pode ser visualizado na Tabela 1.

No Brasil, em 1994-1998, o subgrupo indústria intensiva em escala apresentou maior peso nas exportaçôes totais, seguido dos produtos primários agrícolas e da indústria agroalimentar, o que mostra um padrão de especialização comercial baseado, de um lado, em vantagens comparativas locais com abundância de recursos naturais e, de outro, na existência de setores industriais mais intensivos em escala do que em baixos custos de mão-de-obra (por exemplo, a indústria automobilística, entre outros), que não direcionam a produção apenas para o mercado doméstico, mas também para o mercado internacional.

No período 2001-2005, esse padrão de especialização das exportações brasileiras praticamente não se altera, com exceção do crescimento significativo das exportações da indústria intensiva em P\&D, que atinge $8,7 \%$ de participação no total das exportaçôes, igualando-se à participação da induistria intensiva em trabalho (8,9\%).

Destaca-se que as exportações brasileiras da induistria intensiva em trabalho foram superadas, nesse subgrupo, pelo México e pela Coréia do Sul, em ambos os períodos considerados, sendo um resultado surpreendente em função da oferta elástica de mão-de-obra local. Além disso, os Estados Unidos que revelou uma participação das exportações intensivas em trabalho muito próxima à participação brasileira em 1994-1998 (de 10,1\% contra 10,8\%), no segundo período, apresentou um pequeno aumento dessa participação $(11,6 \%)$, superando a brasileira. A explicação para tal mudança pode estar relacionada a um aumento da imigração para o mercado dos EUA, que tenderia a apresentar uma "oferta elástica de MDO" para a indústria intensiva em trabalho. É bastante provável que, no caso brasileiro, a relação câmbio-salários

3 UNCTAD (2002). O grupo D-7 é formado por Hong Kong (China), Malásia, México, Coréia do Sul, Cingapura, Taiwan e Turquia. 
TABELA 1

Composição das exportações (part. \%) - 1994-1998 e 2001-2005

Brasil e países selecionados

\begin{tabular}{|c|c|c|c|c|c|c|c|c|c|c|c|c|c|}
\hline \multirow[b]{2}{*}{$\begin{array}{l}\text { Cód. } \\
\text { SITC }\end{array}$} & \multirow{2}{*}{$\begin{array}{l}\text { País } \\
\text { TIPOLOGIA PAVITT }\end{array}$} & \multicolumn{2}{|c|}{ Brasil } & \multicolumn{2}{|c|}{ México } & \multicolumn{2}{|c|}{ Coréia do Sul } & \multicolumn{2}{|c|}{ EUA } & \multicolumn{2}{|c|}{ Japão } & \multicolumn{2}{|c|}{ Mundo } \\
\hline & & 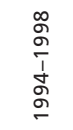 & $\stackrel{\substack{O \\
\grave{1}}}{\frac{1}{8}}$ & 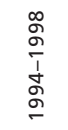 & 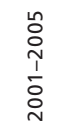 & $\begin{array}{l}\infty \\
\text { ळ̆ } \\
\frac{1}{1} \\
\text { ळ̆ }\end{array}$ & $\frac{n}{\circ}$ & 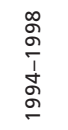 & 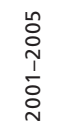 & 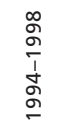 & 嘼 & 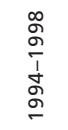 & 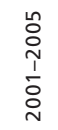 \\
\hline 110 & $\begin{array}{l}\text { Produtos primários } \\
\text { agrícolas }\end{array}$ & 14,6 & 16,5 & 4,2 & 3,0 & 1,1 & 0,6 & 6,9 & 5,7 & 0,2 & 0,2 & 4,8 & 3,8 \\
\hline 120 & $\begin{array}{l}\text { Produtos primários } \\
\text { minerais }\end{array}$ & 6,7 & 6,9 & 1,0 & 0,6 & 0,3 & 0,2 & 1,3 & 1,2 & 0,1 & 0,2 & 1,2 & 1,3 \\
\hline 130 & $\begin{array}{l}\text { Produtos primários } \\
\text { energéticos }\end{array}$ & 0,0 & 2,8 & 9,1 & 10,3 & 0,1 & 0,0 & 0,8 & 0,7 & 0,1 & 0,1 & 3,9 & 6,9 \\
\hline 211 & $\begin{array}{l}\text { Indústria } \\
\text { agroalimentar }\end{array}$ & 13,8 & 11,2 & 2,8 & 2,8 & 1,0 & 0,8 & 4,5 & 4,1 & 0,4 & 0,3 & 5,9 & 5,0 \\
\hline 212 & $\begin{array}{l}\text { Indústria intensiva } \\
\text { em outros } \\
\text { recursos agrícolas }\end{array}$ & 8,4 & 6,7 & 1,2 & 0,5 & 1,5 & 1,2 & 3,0 & 2,1 & 0,5 & 0,6 & 2,9 & 2,3 \\
\hline 213 & $\begin{array}{l}\text { Indústria intensiva } \\
\text { em recursos minerais }\end{array}$ & 6,8 & 5,2 & 3,3 & 2,0 & 7,8 & 6,6 & 5,7 & 5,8 & 4,0 & 4,6 & 5,3 & 5,3 \\
\hline 214 & $\begin{array}{l}\text { Indústria intensiva } \\
\text { em recursos } \\
\text { energéticos }\end{array}$ & 1,0 & 2,3 & 0,6 & 1,1 & 2,9 & 3,4 & 1,4 & 1,1 & 0,5 & 0,5 & 2,2 & 2,5 \\
\hline 221 & $\begin{array}{l}\text { Indústria intensiva } \\
\text { em trabalho }\end{array}$ & 10,8 & 8,9 & 13,8 & 12,7 & 23,0 & 14,6 & 10,1 & 11,6 & 6,2 & 5,9 & 15,5 & 15,3 \\
\hline 222 & $\begin{array}{l}\text { Indústria intensiva } \\
\text { em escala }\end{array}$ & 22,6 & 21,4 & 32,6 & 31,5 & 30,2 & 32,1 & 18,3 & 18,5 & 37,1 & 39,7 & 23,0 & 22,2 \\
\hline 223 & $\begin{array}{l}\text { Fornecedores } \\
\text { especializados }\end{array}$ & 9,4 & 8,5 & 21,7 & 23,3 & 11,6 & 16,5 & 22,9 & 20,1 & 29,1 & 24,5 & 18,2 & 16,3 \\
\hline 224 & $\begin{array}{l}\text { Indústria intensiva } \\
\text { em P\&D }\end{array}$ & 4,5 & 8,7 & 9,7 & 12,0 & 20,5 & 24,0 & 22,1 & 25,5 & 19,3 & 19,3 & 14,5 & 16,3 \\
\hline & Não classificados & 1,3 & 0,9 & 0,1 & 0,1 & 0,0 & 0,0 & 3,0 & 3,6 & 2,4 & 4,2 & 2,7 & 2,8 \\
\hline Total & al das exportações & 100 & 100 & 100 & 100 & 100 & 100 & 100 & 100 & 100 & 100 & 100 & 100 \\
\hline
\end{tabular}

Fonte: elaboração própria, a partir de PC-TAS (1994-1998) e INTRACEN (2001-2005). 
desfavorável às exportações em geral, no período 1994-2005, seja parte da explicação para o baixo desempenho competitivo das exportações intensivas em trabalho, impedindo o aproveitamento das vantagens comparativas brasileiras nesse subgrupo.

Outra experiência de desempenho exportador de país latino-americano é o caso do México, cuja composição setorial das exportaçôes "parece" aproximar-se do padrão brasileiro, pois apresentou uma participação dos setores de exportação pertencentes à indústria intensiva em $P \& D$ muito baixa.

Conforme a tabela anterior, em ambos os períodos analisados, a maior participação das exportações mexicanas se dá na indústria intensiva em escala, seguida do subgrupo fornecedores especializados e, por último, a induistria intensiva em trabalho com a menor participação. Em uma primeira aproximação, as exportações mexicanas concentraram-se em setores com atividades mais complexas, mais intensivos em capital, portanto, de maior valor agregado, o que poderia indicar uma inserção virtuosa no mercado externo. Todavia, deve-se mencionar a presença das maquiladoras na fronteira norte do México destinadas apenas à montagem de produtos para exportação (automóveis e produtos eletroeletrônicos, entre outros), que se baseiam em elevados incentivos fiscais, nos diferenciais de custo de mão-de-obra e na forte dependência do mercado consumidor norte-americano, com baixa capacidade de difusão para o conjunto da indústria mexicana.

Nesse sentido, Capdvielle et al. (1996) tem razão ao afirmar que a especialização virtuosa das exportaçōes mexicanas (principalmente das maquiladoras) não foi acompanhada de um desenvolvimento de capacidades tecnológicas que permitisse fortes linkages intersetoriais e difundisse os efeitos do dinamismo exportador para o conjunto da economia, independentemente dos baixos custos de mão-de-obra e da oferta de recursos naturais. Entretanto, ao longo do processo de abertura comercial, alguns elementos de uma política industrial ativa com seletividade setorial presentes no período anterior à reforma de abertura econômica até meados da década de 1980 foram retomados nos anos de 1994 a 2000, em determinadas indústrias, a saber: automobilística, microcomputadores e petroquímica. Tais indústrias foram contempladas com proteção tarifária e programas de fomento associados a metas de desempenho produtivo e exportador (Ferreira Jr., 1995; Além, 1996). 
Segundo Moreno-Brid et al. (2005), na prática, a ausência de melhores condiçõos de financiamento e a lenta implementação das políticas industriais seletivas explicam os resultados limitados alcançados em termos de ampliação da participação do México na cadeia de valor das manufaturas mundial. Portanto, a isenção tarifária sobre insumos importados utilizados na indústria de reexportação permanece como o principal instrumento da política industrial mexicana. Nesse sentido, as exportações mexicanas de manufaturas seguem apresentando forte dependência de insumos importados, caracterizadas por uma reduzida parcela de conteúdo local e fracos encadeamentos intersetoriais (cerca de $70 \%$ das exportações de manufaturas são produzidas através de atividades de processamento envolvendo insumos importados sob políticas tarifárias preferenciais).

A participação das exportações da indústria intensiva em P\&D mexicana é mais elevada que a participação brasileira. No primeiro período, o México apresentou uma participação de 9,7\% contra 4,5\% do Brasil, enquanto, no segundo período, esse valor passou para $12 \%$ contra $8,7 \%$ do Brasil. No México, constata-se também que as exportações da indústria intensiva em escala $\mathrm{e}$ fornecedores especializados somam aproximadamente 55\% da participação das exportações em 2001-2005, enquanto, no caso do Brasil, aproximadamente $50 \%$ da participação das exportações se dá em primários agrícolas, indústria agroalimentar e industria intensiva em escala.

Uma terceira experiência de inserção comercial de país em desenvolvimento refere-se ao caso sul-coreano. De imediato, nota-se que a composição setorial da Coréia do Sul é bastante similar ao caso dos países desenvolvidos, como se verá adiante, pois apresentou uma participação das exportações da indústria intensiva em $P \& D$ superior a $20 \%$.

Pode-se destacar que a queda da indústria intensiva em trabalho $(23 \% \mathrm{em}$ 1994-1998 para 14,6\% em 2001-2005) foi compensada, principalmente, pela elevação da participação em fornecedores especializados (11,6\% para 16,5\%). Um segundo destaque é a elevada participação das exportações no subgrupo indústria intensiva em $P \& D$, cujos valores são bem mais expressivos que os casos brasileiro e mexicano. No período 1994-1998, essa participação foi de 20,5\%, subindo para 24\% em 2001-2005. 
Notou-se também uma elevação da participação entre 1994-1998 e 2001-2005 dos subgrupos indústria intensiva em recursos energéticos, que passou de 2,9\% para 3,4\%, e indústria intensiva em escala, que passou de $30,2 \%$ para $32,1 \%$. Os subgrupos induistria intensiva em escala, fornecedores especializados e indústria intensiva em $P \& D$ juntos têm uma participação de aproximadamente $72 \%(32,1 \%+16,5 \%+24 \%)$ em 2001-2005.

É preciso ressaltar que este tal upgrading das exportações sul-coreanas foi obtido durante as décadas de 1960 e 1970, em que a política industrial se caracterizou como tendo sido uma política de substituição de importações com um elevado grau de seletividade setorial e fortemente subordinada à estratégia de aquisição de competitividade internacional, diferentemente da América Latina, onde o nível de proteção comercial e o sistema de concessão de incentivos foram utilizados genericamente sem nenhuma convergência de atividades industriais específicas (Fajnzylber, 1983:90; Santos Filho \& Ferreira Jr., 1989:381). Simultaneamente, os gastos crescentes em P\&D permitiram à indústria coreana formação de capacidades tecnológicas locais e aquisição de competitividade internacional nas indústrias eletrônica e automobilística, com marcas, design e fabricação própria (Canuto, 1994).

Em termos comparativos, este artigo selecionou outras duas experiências de inserção comercial de países desenvolvidos, considerados virtuosos no desempenho exportador de produtos de alta intensidade tecnológica: EUA e Japão.

Em primeiro lugar, a maior parte do total das exportações norte-americanas está concentrada na indústria intensiva em escala, fornecedores especializados e indústria intensiva em P\&D, somando, em 2001-2005, 64\% (18,5\% + 20,1\% + $25,5 \%)$, revelando, portanto, um padrão de especialização das exportações baseado em setores mais dinâmicos, que possuem uma elasticidade-renda alta, caracterizados por um ritmo elevado de atividades de inovação, conformando uma estrutura das exportações mais intensiva em tecnologia.

Em segundo lugar, na estrutura de exportações dos EUA, segundo a tipologia Pavitt, destaca-se a indústria intensiva em P\&D, cuja participação das exportaçóes passou de $22,1 \%$ para $25,5 \%$ no período, revelando-se a maior participação no total das exportaçôes dos EUA e também a maior participação nesse subgrupo entre todos os países selecionados, sem nenhuma exceção. 
Em um primeiro momento, observando os resultados obtidos em termos da participação relativa, pode-se dizer que as exportações norte-americanas da indústria intensiva em P\&D em 2001-2005 atingiram um padrão tecnológico centrado na produção em série de produtos diferenciados, com alta qualidade e preços competitivos, destacando-se a evolução de setores como aeronaves, equipamentos de telecomunicações e semicondutores, ${ }^{4}$ completando o circuito inovativo na economia norte-americana, solucionando as limitações apontadas por Amable e Boyer (1993) quanto à incapacidade da indústria dos EUA de promover uma transição rápida na direção de um padrão tecnológico intensivo em $\mathrm{P} \& \mathrm{D}$. Todavia, para explorar melhor tais resultados, deve ser considerada ainda a análise da evolução do indicador de market-share, o que será feito adiante.

Ao longo da década de 1980, operou-se um processo de upgrading tecnológico da indústria japonesa, assistindo-se à crescente presença de produtos de alta tecnologia made in Japan no mercado internacional. É nesse momento que se processa a transição da fase de catching up para a disputa da liderança tecnológica mundial e o país se posicionou melhor comparativamente aos demais pela capacidade de se adaptar às novas condições impostas pelo paradigma baseado na microeletrônica, então em processo de conformação e difusão (Freeman, 1987).

Diante disso, observou-se a experiência recente da composição das exportações do Japão, segundo a classificação Pavitt. A maior parte das exportações está concentrada nos subgrupos indústria intensiva em escala, fornecedores especializados e indústria intensiva em P\&D, totalizando, aproximadamente, $83 \%(39,7 \%+24,5 \%+19,3 \%)$ no período de 2001-2005.

Tal estrutura da composição das exportações japonesas é similar aos casos sul-coreano e norte-americano, embora o peso da indústria intensiva em escala seja superior à inserção externa da Coréia do Sul e, principalmente, à inserção das exportações norte-americanas. Adicionalmente, não foram notadas grandes oscilações entre um período e outro no caso japonês, o que demonstra certa maturidade e estabilização de seu padrão de especialização comercial, com exceção da queda observada no subgrupo fornecedores especializados, que caiu de $29,1 \%$ para $24,5 \%$ no período.

4 A análise da indústria intensiva em P\&D para os setores desagregados é apresentada na Tabela 4. 
Por último, a análise da participação das exportações mundiais segundo a intensidade tecnológica revela uma queda observada no subgrupo fornecedores especializados, que passou de 18,2\% em 1994-1998 para 16,3\% em 2001-2005, sendo acompanhada pela elevação da participação das exportações na induistria intensiva em $P \& D$, que variou de $14,5 \%$ para $16,3 \%$ no mesmo período. Um segundo destaque refere-se ao subgrupo produtos primários energéticos, que cresceu no período, passando de 3,9\% para 6,9\%. Os demais subgrupos não apresentaram grandes oscilações.

Portanto, pode-se afirmar que o crescimento da participação das exportações dos países selecionados no subgrupo indústria intensiva em P\&D (à exceção do Japão, em que essa participação se manteve constante) está acompanhando o ritmo de crescimento das exportaçôes mundiais nesse subgrupo no período, enquanto no caso do subgrupo fornecedores especializados, apesar da queda observada, se constatou que, no México e na Coréia do Sul, essa indústria apresentou crescimento, o que é um resultado não-convergente com a composição das exportações mundiais.

Procurando confrontar o desempenho de cada país com a evolução das exportações mundiais, são apresentadas a seguir as taxas de crescimento dos valores brutos das exportaçoos (Tabela 2) e o indicador de market-share para os países selecionados (Tabela 3).

Em relação ao Brasil, pode-se dizer que o crescimento observado entre o período 1994-1998 e 2001-2005, nos subgrupos produtos primários energéticos e indústria intensiva em recursos energéticos, representados pelos setores de combustíveis minerais, lubrificantes e outros, está relacionado às mudanças no comércio mundial, como o crescimento econômico acelerado da China, que tem direcionado parcela cada vez maior de eletrointensivos (minério de ferro, produtos siderúrgicos, entre outros) para o mercado externo. Em segundo lugar, a recente alta dos preços do petróleo e a demanda externa crescente por combustíveis renováveis, o que acelerou os investimentos para ampliação da produção de álcool via cana-de-açúcar. No entanto, vale mencionar que as exportações de álcool ainda são incipientes. Observando a participação relativa das exportaçôes brasileiras do "complexo sucroalcooleiro" sobre o total das exportações do agronegócio, apesar do aumento da importância do álcool (cresceu de 0,2\% em 1997 para 3,25\% em 2006), seu resultado é 
TABELA 2

Taxa de crescimento das exportações - 1994-1998

e 2001-2005 - Brasil e países selecionados (em \%)

\begin{tabular}{|c|c|c|c|c|c|c|c|}
\hline & País & Brasil & México & Coréia do Sul & EUA & Japão & Mundo \\
\hline $\begin{array}{l}\text { Cód. } \\
\text { SITC }\end{array}$ & Tipologia Pavitt & & & & & & \\
\hline 110 & $\begin{array}{l}\text { Produtos primários } \\
\text { agrícolas }\end{array}$ & 87,9 & 35,4 & $-21,7$ & 1,1 & 47,7 & 27,6 \\
\hline 120 & $\begin{array}{l}\text { Produtos primários } \\
\text { minerais }\end{array}$ & 71,5 & 15,9 & 2,4 & 8,8 & 106,1 & 63,1 \\
\hline 130 & $\begin{array}{l}\text { Produtos primários } \\
\text { energéticos }\end{array}$ & 12758,0 & 117,6 & 7,8 & 8,4 & 7,2 & 185,8 \\
\hline 211 & Indústria agroalimentar & 35,1 & 89,0 & 23,3 & 10,7 & $-10,1$ & 34,0 \\
\hline 212 & $\begin{array}{l}\text { Indústria intensiva em } \\
\text { outros recursos agrícolas }\end{array}$ & 34,2 & $-13,6$ & 24,3 & $-13,6$ & 35,3 & 23,2 \\
\hline 213 & $\begin{array}{l}\text { Indústria intensiva } \\
\text { em recursos minerais }\end{array}$ & 27,6 & 16,2 & 28,8 & 23,0 & 35,1 & 60,0 \\
\hline 214 & $\begin{array}{l}\text { Indústria intensiva em } \\
\text { recursos energéticos }\end{array}$ & 294,3 & 220,3 & 82,4 & 2,9 & 19,8 & 83,5 \\
\hline 221 & $\begin{array}{l}\text { Indústria intensiva } \\
\text { em trabalho }\end{array}$ & 37,8 & 76,1 & $-3,0$ & 38,7 & 14,5 & 56,1 \\
\hline 222 & $\begin{array}{l}\text { Indústria intensiva } \\
\text { em escala }\end{array}$ & 58,0 & 85,7 & 62,5 & 22,0 & 27,5 & 53,4 \\
\hline 223 & $\begin{array}{l}\text { Fornecedores } \\
\text { especializados }\end{array}$ & 50,7 & 106,0 & 116,7 & 6,4 & 0,1 & 42,0 \\
\hline 224 & $\begin{array}{l}\text { Indústria intensiva } \\
\text { em P\&D }\end{array}$ & 218,4 & 138,7 & 79,3 & 39,8 & 18,8 & 78,1 \\
\hline \multicolumn{2}{|c|}{ Total das exportações } & 66,8 & 91,6 & 53,0 & 21,2 & 19,2 & 58,6 \\
\hline
\end{tabular}

Fonte: elaboração própria, a partir de PC-TAS (1994-1998) e INTRACEN (2001-2005).

superado pelas exportações de açúcar (cresceram de 7,6\% para 12,48\% no mesmo período). ${ }^{5}$

Todos os países apresentaram crescimento positivo no caso da indústria intensiva em $P \& D$, e as taxas de crescimento mais elevadas foram observadas nas exportações brasileiras, em primeiro lugar, e nas exportações mexicanas, em segundo lugar, e devem-se, além da busca pela modernização tecnológica

5 Segundo AgroStat Brasil, a partir de dados da SECEX/MDIC. Elaboração: CGOE/DPI/SRI/MAPA. Disponível em <http:// www.agricultura.gov.br>. 
de tais países, ao baixo patamar observado no período 1994-1998, o que não é o caso da Coréia do Sul e dos países desenvolvidos que já possuíam uma concentração elevada das exportações nesse subgrupo no, início do período, analisado.

Considerando a variação das exportações mundiais nos períodos de 1994-1998 e 2001-2005, as maiores taxas de crescimento ocorreram nos subgrupos produtos primários energéticos, indústria intensiva em recursos energéticos e induistria intensiva em $P \& D$, indicando que o Brasil está crescendo em setores dinâmicos (em que a demanda mundial está crescendo), a despeito de se tratarem de setores com baixo valor agregado. No que se refere ao crescimento da indústria intensiva em P\&D, segundo o relatório da UNCTAD (2002), os setores de manufaturas intensivos em tecnologia apresentaram um crescimento no comércio bem mais rápido do que os setores intensivos em mão-de-obra e recursos naturais, apesar de alguns produtos nesses setores apresentarem dinamismo considerável (como é o caso dos recursos energéticos, como visto aqui).

A razão para essas diferenças não está apenas no diferencial em termos de elasticidade-renda (que é maior para os bens intensivos em tecnologia), mas se deve também às políticas adotadas pelos países em desenvolvimento que ampliaram o acesso aos mercados, o que envolveu as medidas de liberalização comercial e o crescimento da mobilidade do capital diante das restrições quanto à mobilidade do fator trabalho, estendendo a possibilidade de constituição de redes de produção internacionais em vários produtos que podem ter seus processos de produção localizados em diferentes países, de acordo com a dotação de fatores e custos.

Em relação ao desempenho dos países, apesar de o crescimento dos países em desenvolvimento na indústria intensiva em $P \& D$ ser igual ou superior à taxa de crescimento das exportações mundiais nesse subgrupo $(78,1 \%$, conforme Tabela 2), o indicador de market-share ainda possui uma base bastante limitada para tais países (0,6\% para o Brasil, 1,8\% para o México, 3,8\% para a Coréia do Sul em 2001-2005) vis-à-vis os resultados apresentados pelos países desenvolvidos.

Nota-se, no entanto, que a parcela de mercado dos países desenvolvidos está caindo, enquanto os países em desenvolvimento têm apresentado 
TABELA 3

Market-share das exportações - 1994-1998 e 2001-2005 - Brasil e países selecionados (em \%)

\begin{tabular}{|c|c|c|c|c|c|c|c|c|c|c|c|}
\hline \multirow[b]{2}{*}{$\begin{array}{l}\text { Cód. } \\
\text { SITC }\end{array}$} & \multirow{2}{*}{$\begin{array}{l}\text { País } \\
\text { Tipologia Pavitt }\end{array}$} & \multicolumn{2}{|c|}{ Brasil } & \multicolumn{2}{|c|}{ México } & \multicolumn{2}{|c|}{ Coréia do Sul } & \multicolumn{2}{|c|}{ EUA } & \multicolumn{2}{|c|}{ Japão } \\
\hline & & $\begin{array}{l}\infty \\
\stackrel{2}{\sigma} \\
\frac{1}{1} \\
\stackrel{2}{\circ}\end{array}$ & $\begin{array}{l}\stackrel{n}{0} \\
\stackrel{1}{N} \\
\frac{1}{8} \\
\stackrel{N}{N}\end{array}$ & $\begin{array}{l}\infty \\
\stackrel{\infty}{\sigma} \\
\frac{1}{5} \\
\stackrel{5}{\circ}\end{array}$ & 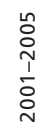 & $\begin{array}{l}\infty \\
\stackrel{2}{\sigma} \\
\frac{1}{1} \\
\stackrel{5}{\sigma}\end{array}$ & 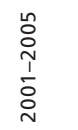 & $\begin{array}{l}\infty \\
\stackrel{2}{\sigma} \\
\frac{1}{1} \\
\text { } \\
\frac{5}{-}\end{array}$ & 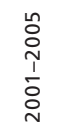 & $\begin{array}{l}\infty \\
\stackrel{2}{\sigma} \\
\frac{1}{1} \\
\text { Oे } \\
\sigma\end{array}$ & $\begin{array}{l}\stackrel{n}{0} \\
\stackrel{0}{N} \\
\frac{1}{0} \\
\stackrel{0}{N}\end{array}$ \\
\hline 110 & $\begin{array}{l}\text { Produtos primários } \\
\text { agrícolas }\end{array}$ & 3,3 & 4,7 & 1,8 & 1,9 & 0,7 & 0,4 & 18,4 & 14,8 & 0,3 & 0,4 \\
\hline 120 & $\begin{array}{l}\text { Produtos primários } \\
\text { minerais }\end{array}$ & 5,9 & 6,0 & 1,6 & 1,1 & 0,7 & 0,4 & 13,9 & 9,6 & 0,9 & 1,1 \\
\hline 130 & $\begin{array}{l}\text { Produtos primários } \\
\text { energéticos }\end{array}$ & 0,0 & 0,4 & 5,0 & 3,6 & 0,1 & 0,0 & 2,8 & 1,0 & 0,2 & 0,1 \\
\hline 211 & $\begin{array}{l}\text { Indústria } \\
\text { agroalimentar }\end{array}$ & 2,5 & 2,5 & 1,0 & 1,4 & 0,5 & 0,4 & 9,9 & 8,3 & 0,7 & 0,4 \\
\hline 212 & $\begin{array}{l}\text { Indústria intensiva } \\
\text { em outros recursos } \\
\text { agrícolas }\end{array}$ & 3,1 & 3,3 & 0,8 & 0,6 & 1,5 & 1,5 & 13,1 & 9,2 & 1,7 & 1,8 \\
\hline 213 & $\begin{array}{l}\text { Indústria intensiva } \\
\text { em recursos minerais }\end{array}$ & 1,4 & 1,1 & 1,3 & 0,9 & 4,0 & 3,2 & 13,8 & 10,8 & 7,0 & 5,9 \\
\hline 214 & $\begin{array}{l}\text { Indústria intensiva } \\
\text { em recursos } \\
\text { energéticos }\end{array}$ & 0,5 & 1,1 & 0,6 & 1,2 & 3,7 & 3,4 & 8,1 & 4,7 & 2,1 & 1,4 \\
\hline 221 & $\begin{array}{l}\text { Indústria intensiva } \\
\text { em trabalho }\end{array}$ & 0,7 & 0,7 & 1,8 & 2,1 & 0,7 & 2,6 & 8,4 & 7,5 & 3,6 & 2,7 \\
\hline 222 & $\begin{array}{l}\text { Indústria intensiva } \\
\text { em escala }\end{array}$ & 1,1 & 1,1 & 2,9 & 3,6 & 3,6 & 3,8 & 10,2 & 8,4 & 14,9 & 12,3 \\
\hline 223 & $\begin{array}{l}\text { Fornecedores } \\
\text { especializados }\end{array}$ & 0,6 & 0,6 & 2,4 & 3,6 & 1,7 & 2,6 & 16,1 & 12,3 & 14,8 & 10,3 \\
\hline 224 & $\begin{array}{l}\text { Indústria intensiva } \\
\text { em P\&D }\end{array}$ & 0,3 & 0,6 & 1,3 & 1,8 & 3,8 & 3,8 & 19,4 & 15,6 & 12,4 & 8,1 \\
\hline
\end{tabular}

Fonte: elaboração própria, a partir de PC-TAS (1994-1998) e INTRACEN (2001-2005).

crescimento das exportações nesses setores. Observou-se que as exportações da indústria intensiva em P\&D dos EUA e do Japão apresentaram um crescimento inferior à média mundial (de 21,2\% e 19,2\%, respectivamente, contra 58,6\% no mundo) em 2001-2005, além disso, conforme a Tabela 3, o indicador de market-share desses países sofreu uma redução, cerca de quatro pontos percentuais. Nesse sentido, os resultados parecem sugerir que os EUA e o Japão estão reduzindo sua importância no comércio internacional, 
e, no caso dos setores de exportação de maior conteúdo tecnológico, essa queda é mais lenta.

É importante considerar, no entanto, como mostra o relatório da UNCTAD (2002), que o crescimento das exportações de manufaturados observado para os países em desenvolvimento não significou aumento correspondente da participação desses países na renda e produção mundial de manufaturas, isso porque, com algumas exceções na região asiática, tais países estiveram concentrados em etapas dos processos de produção de baixo valor agregado. Portanto, a conclusão de que pode estar-se configurando uma importante mudança no padrão de especialização comercial, entre os países industrializados e os países emergentes, deve ser relativizada pelo fato de que tal mudança, com a ampliação da participação dos países em desenvolvimento nos fluxos de investimento e comércio mundiais, está sendo "puxada" pelos países asiáticos que apresentaram um melhor desempenho no comércio internacional dentre os países em desenvolvimento.

Em conformidade com o escopo do presente trabalho, deve-se destacar, particularmente, os resultados da indústria intensiva em $P \& D$ e seus efeitos para o desempenho exportador dos países. Para isso, apresentou-se os dados desagregados para esse subgrupo, vale dizer, os setores de exportação em nível de 3 dígitos segundo a SITC, o que pode ser visualizado na Tabela 4.

No caso do padrão de exportaçôes do Brasil, constata-se que a maioria dos setores da indústria intensiva em $P \& D$ apresentou queda de participação entre o período 1994-1998 e 2001-2005, com exceção de apenas três setores: "equipamentos de telecomunicações" e "aeronaves", que obtiveram uma participação expressiva no total das exportações do subgrupo (respectivamente, 24,3\% e 43,2\% em 2001-2005), e "instrumentos de óptica". Isso se repetiu também na experiência de inserção externa do México, onde as exportações estão fortemente concentradas apenas no setor "equipamentos de telecomunicaçôes”, com uma participação de 46,8\% em 2001-2005. Destaca-se também a queda da participação do setor "lâmpadas, tubos e válvulas de cátodo", que passou de $17,6 \%$ para $10,2 \%$ em 2001-2005.

No que tange às exportaçôes da indústria intensiva em $P \& D$ da Coréia do Sul, dos 20 setores que compõem esse subgrupo, 15 setores mantiveram ou melhoraram sua participação, e os 5 setores restantes perderam participação 
de um período para o outro. Destacam-se os setores "lâmpadas, tubos e válvulas de cátodo", cuja queda na participação ocorreu em contraposição ao aumento de participação do setor "equipamentos de telecomunicações".

Por outro lado, os dados desagregados para a indústria intensiva em $P \& D$ dos EUA mostram que apenas 7 setores perderam participação, e os demais setores elevaram sua participação ou pelo menos mantiveram estável tal participação das exportações. Destaca-se o setor "aeronaves", que apresentou a maior queda de participação, passando de 27,6\% para 24,7\%, seguido do setor "equipamentos de telecomunicaçôes" e "lâmpadas, tubos e válvulas de cátodo". Coincidentemente, conforme foi demonstrado anteriormente, é exatamente nos setores de "aeronaves" e "equipamentos de telecomunicações" da indústria intensiva em $P \& D$ que o Brasil obteve um desempenho positivo, revelando que o comércio entre os dois países nesse setor não é complementar, considerando também que tais países atendem segmentos de mercado bastante distintos, e o Brasil se destaca no segmento de avióes de pequeno porte.

A análise desagregada das exportações da indústria intensiva em $P \& D$ do Japão mostra que, dentre os 20 setores que correspondem ao subgrupo industria intensiva em $P \& D, 12$ setores mantiveram ou ganharam participação no período recente, destacando-se os setores de "fibra de ótica" e "instrumentos de medição" e "produtos químicos". Entretanto, ocorreram quedas de participação significativas nos setores "equipamentos de telecomunicações" e "lâmpadas, tubos e válvulas de cátodo".

A análise desagregada a 3 dígitos para o subgrupo indústria intensiva em $P \& D$ foi estendida para o indicador de market-share, como mostra a Tabela 5 , o que permite aprofundar as conclusões até então alcançadas sobre as mudanças no padrão de especialização comercial entre os países em desenvolvimento e os países desenvolvidos.

Observou-se que, no caso do Brasil, o pequeno aumento de market-share nesse subgrupo foi "puxado" pelos setores "alcoóis e fenóis", "aeronaves" e "equipamentos de telecomunicações”. Em comparação ao Brasil, as exportações mexicanas da indústria intensiva em $P \& D$ apresentaram um resultado superior (1,8\% contra $0,6 \%$ do Brasil, em 2001-2005), com uma ampliação do market-share, em quase todos os setores pertencentes a esse subgrupo (à exceção de três setores, sejam eles "alcoóis e fenóis", "produtos medicinais e farmacêuticos" e "aeronaves"). 
TABELA 4

Composição setorial das exportações da indústria intensiva em $P \& D$

1994-1998 e 2001-2005 - Brasil e países selecionados (em \%)

\begin{tabular}{|c|c|c|c|c|c|c|c|c|c|c|c|c|c|}
\hline & País & & asil & Méx & kico & Coréia & do Sul & EU & & Jap & ão & Mun & \\
\hline Cód. & $\begin{array}{l}\text { Indústria intensiva } \\
\text { em P\&D }\end{array}$ & 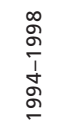 & 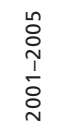 & 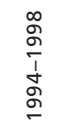 & 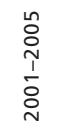 & 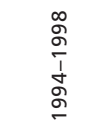 & 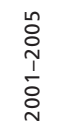 & 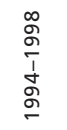 & 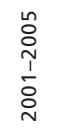 & 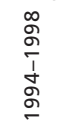 & 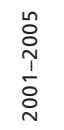 & 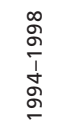 & $\begin{array}{l}\text { n } \\
\stackrel{\circ}{+} \\
\frac{1}{0} \\
\stackrel{i}{N}\end{array}$ \\
\hline 512 & Álcoois e fenóis & 8,7 & 6,7 & 1,4 & 0,3 & 0,5 & 0,9 & 1,4 & 1,4 & 1,1 & 1,2 & 1,8 & 1,7 \\
\hline 531 & Tinturas sintéticas & 3,2 & 0,9 & 0,6 & 0,4 & 0,9 & 0,6 & 0,5 & 0,4 & 0,8 & 0,4 & 1,5 & 0,8 \\
\hline 532 & Tinturas e "extratos" & 1,7 & 0,5 & 0,4 & 0,1 & 0,0 & 0,0 & 0,0 & 0,0 & 0,0 & 0,0 & 0,1 & 0,1 \\
\hline 533 & Pigmentos e pinturas & 3,8 & 1,8 & 1,6 & 1,7 & 0,9 & 1,2 & 1,8 & 2,1 & 1,7 & 2,2 & 2,9 & 2,7 \\
\hline 541 & $\begin{array}{l}\text { Produtos medicinais } \\
\text { e farmacêuticos }\end{array}$ & 4,9 & 1,9 & 3,2 & 1,6 & 0,8 & 0,5 & 3,5 & 4,9 & 1,4 & 1,2 & 4,0 & 4,3 \\
\hline 542 & $\begin{array}{l}\text { Medicamentos } \\
\text { incluindo veterinários }\end{array}$ & 3,8 & 3,2 & 2,6 & 4,4 & 0,3 & 0,4 & 2,3 & 6,4 & 0,9 & 2,1 & 7,6 & 13,1 \\
\hline 551 & Essências e perfumes & 3,7 & 1,7 & 0,5 & 0,5 & 0,0 & 0,0 & 0,6 & 0,7 & 0,2 & 0,2 & 0,9 & 1,0 \\
\hline 553 & $\begin{array}{l}\text { Produtos de } \\
\text { perfumaria e } \\
\text { cosméticos }\end{array}$ & 2,3 & 2,2 & 1,3 & 2,1 & 0,2 & 0,5 & 1,7 & 2,2 & 0,5 & 0,7 & 2,9 & 2,9 \\
\hline 554 & $\begin{array}{l}\text { Sabão e produtos } \\
\text { de limpeza }\end{array}$ & 2,8 & 1,5 & 1,9 & 1,9 & 0,4 & 0,4 & 1,0 & 1,1 & 0,5 & 0,6 & 1,7 & 1,5 \\
\hline 598 & $\begin{array}{l}\text { Produtos químicos } \\
\text { diversos }\end{array}$ & 6,3 & 2,4 & 1,9 & 1,4 & 1,4 & 1,8 & 4,3 & 4,8 & 3,8 & 5,8 & 4,4 & 4,3 \\
\hline 764 & $\begin{array}{l}\text { Equipamentos de } \\
\text { telecomunicações }\end{array}$ & 6,3 & 24,3 & 41,4 & 46,8 & 17,0 & 50,4 & 14,3 & 13,2 & 20,1 & 15,4 & 17,4 & 21,2 \\
\hline 776 & $\begin{array}{l}\text { Lâmpadas, tubos e } \\
\text { válvulas de cátodo }\end{array}$ & 4,5 & 3,0 & 17,6 & 10,2 & 69,4 & 41,1 & 20,9 & 19,6 & 42,1 & 37,4 & 24,0 & 17,9 \\
\hline 792 & Aeronaves & 28,7 & 43,2 & 4,0 & 1,4 & 1,9 & 0,7 & 27,6 & 24,7 & 1,3 & 1,5 & 12,7 & 9,8 \\
\hline 871 & $\begin{array}{l}\text { Instrumentos } \\
\text { de óptica }\end{array}$ & 0,1 & 0,1 & 0,1 & 0,2 & 2,4 & 5,9 & 0,7 & 1,2 & 2,0 & 3,7 & 0,9 & 2,1 \\
\hline 872 & $\begin{array}{l}\text { Instrumentos } \\
\text { e aparelhos de } \\
\text { medicina }\end{array}$ & 1,8 & 1,3 & 6,8 & 10,3 & 0,3 & 0,5 & 4,1 & 5,2 & 1,8 & 1,7 & 3,0 & 3,4 \\
\hline 873 & $\begin{array}{l}\text { Medidores e } \\
\text { contadores }\end{array}$ & 2,0 & 0,7 & 1,5 & 1,7 & 0,1 & 0,1 & 0,4 & 0,4 & 0,5 & 0,4 & 0,5 & 0,5 \\
\hline 874 & $\begin{array}{l}\text { Instrumentos e } \\
\text { aparelhos de medição }\end{array}$ & 4,0 & 2,4 & 7,9 & 11,0 & 1,3 & 1,4 & 11,1 & 11,9 & 8,6 & 10,5 & 8,0 & 7,6 \\
\hline 881 & $\begin{array}{l}\text { Equipamentos } \\
\text { fotográficos }\end{array}$ & 0,2 & 0,0 & 1,5 & 1,6 & 0,8 & 0,3 & 0,8 & 0,6 & 5,1 & 4,6 & 1,7 & 1,4 \\
\hline 882 & Materiais fotográficos & 10,3 & 1,9 & 2,9 & 1,9 & 0,3 & 0,3 & 1,9 & 1,6 & 4,9 & 4,4 & 2,5 & 1,6 \\
\hline 884 & Fibras de óptica & 1,0 & 0,4 & 0,9 & 0,7 & 1,2 & 1,4 & 1,1 & 1,6 & 2,7 & 6,1 & 1,5 & 2,0 \\
\hline $\begin{array}{l}\text { Total } \\
\text { subg }\end{array}$ & $\begin{array}{l}\text { I das exportações do } \\
\text { grupo }\end{array}$ & 100 & 100 & 100 & 100 & 100 & 100 & 100 & 100 & 100 & 100 & 100 & 100 \\
\hline
\end{tabular}

Fonte: elaboração própria, a partir de PC-TAS (1994-1998) e INTRACEN (2001-2005). 
Em relação à Coréia do Sul, observando o market-share do total das exportaçõos do subgrupo, viu-se que este não variou, e as principais mudanças dentre os setores que fazem parte do subgrupo envolveram o setor de semicondutores (SITC 776), que apresentou uma queda significativa (de $11,1 \%$ para $6,2 \%$ ), e o setor de telecomunicações (SITC 764), com um aumento de $3,8 \%$ para $9 \%$.

No caso dos países desenvolvidos, a queda observada para o indicador de market-share no subgrupo, em termos desagregados, revela que, tanto nos EUA como no Japão, houve uma redução do market-share na maior parte dos setores considerados a 3 dígitos. Além disso, os ganhos obtidos em alguns poucos setores, como é o caso do setor "fibras de óptica" no Japão, que se elevou de $21,8 \%$ para $24,7 \%$, foram acompanhados por perdas de market-share de maior relevância, como é o caso do setor "equipamentos de telecomunicaçôes", que caiu de $16 \%$ para $9,8 \%$ nos EUA, e do setor "instrumentos de óptica", que caiu de $27,9 \%$ para $16,6 \%$ no Japão.

No geral, pode-se dizer que, em comparação aos casos dos EUA e Japão, os países em desenvolvimento selecionados obtiveram um melhor desempenho no subgrupo indistria intensiva em $P \& D$, com a maior parte dos setores apresentando uma ampliação do indicador de market-share, enquanto os países desenvolvidos obtiveram um resultado oposto, com uma perda de market-share na maior parte dos setores. Portanto, a análise dos dados desagregados corrobora os resultados anteriores, apontando para um crescimento da importância dos países em desenvolvimento nas exportações dos setores de alta intensidade tecnológica diante da redução dessa importância pelos países desenvolvidos.

Por último, buscando enfatizar as assimetrias observadas entre os países em desenvolvimento (Brasil, México e Coréia do Sul) e os países desenvolvidos (EUA e Japão), o indicador de market-share foi recalculado, considerando a importância dos países selecionados diante do total das exportaçōes da amostra de países, ao invés do total das exportaçóes do mercado mundial. Os resultados são apresentados na Tabela 6.

Observou-se que os EUA têm o melhor desempenho exportador dentre os países da amostra, apresentando os maiores valores de market-share em todos os subgrupos (à exceção do subgrupo produtos primários energéticos, em que o 
TABELA 5

Market-share das exportações da indústria intensiva em P\&D 1998 e 2005 - Brasil e países selecionados (em \%)

\begin{tabular}{|c|c|c|c|c|c|c|c|c|c|c|c|}
\hline \multirow[b]{2}{*}{ Cód. } & \multirow{2}{*}{$\begin{array}{l}\text { País } \\
\text { Indústria intensiva } \\
\text { em P\&D }\end{array}$} & \multicolumn{2}{|c|}{ Brasil } & \multicolumn{2}{|c|}{ México } & \multicolumn{2}{|c|}{ Coréia do Sul } & \multicolumn{2}{|c|}{ EUA } & \multicolumn{2}{|c|}{ Japão } \\
\hline & & 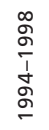 & $\begin{array}{l}n \\
\stackrel{0}{0} \\
\stackrel{1}{1} \\
\stackrel{0}{0}\end{array}$ & 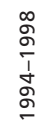 & 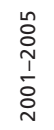 & $\begin{array}{l}\infty \\
\stackrel{2}{\sigma} \\
\frac{1}{1} \\
\stackrel{5}{\sigma} \\
\stackrel{-}{\sigma}\end{array}$ & $\begin{array}{l}\text { n } \\
\stackrel{\circ}{0} \\
\stackrel{1}{1} \\
\stackrel{0}{0}\end{array}$ & \begin{tabular}{l}
$\infty$ \\
$\stackrel{2}{\circ}$ \\
$\stackrel{1}{1}$ \\
\multirow{2}{*}{} \\
$\stackrel{-}{\sigma}$
\end{tabular} & $\begin{array}{l}n \\
\stackrel{0}{0} \\
\stackrel{1}{1} \\
\frac{1}{0} \\
\stackrel{N}{N}\end{array}$ & 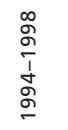 & 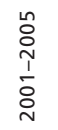 \\
\hline 512 & Álcoois e fenóis & 1,6 & 2,2 & 1,0 & 0,4 & 1,0 & 2,0 & 15,3 & 12,7 & 7,1 & 5,6 \\
\hline 531 & Tinturas sintéticas & 0,7 & 0,6 & 0,5 & 0,8 & 2,3 & 2,7 & 6,2 & 6,5 & 6,5 & 3,7 \\
\hline 532 & Tinturas e "extratos" & 4,6 & 2,9 & 3,9 & 2,0 & 0,5 & 0,8 & 4,2 & 5,9 & 1,5 & 1,6 \\
\hline 533 & Pigmentos e pinturas & 0,4 & 0,4 & 0,8 & 1,2 & 1,2 & 1,7 & 11,8 & 12,0 & 7,2 & 6,6 \\
\hline 541 & $\begin{array}{l}\text { Produtos medicinais } \\
\text { e farmacêuticos }\end{array}$ & 0,4 & 0,3 & 1,1 & 0,7 & 0,8 & 0,5 & 17,3 & 17,3 & 4,4 & 2,2 \\
\hline 542 & $\begin{array}{l}\text { Medicamentos } \\
\text { incluindo veterinários }\end{array}$ & 0,2 & 0,1 & 0,5 & 0,6 & 0,1 & 0,1 & 6,0 & 7,7 & 1,4 & 1,4 \\
\hline 551 & Essências e perfumes & 1,4 & 1,0 & 0,7 & 0,9 & 0,0 & 0,0 & 13,6 & 10,1 & 2,7 & 1,5 \\
\hline 553 & $\begin{array}{l}\text { Produtos de perfumaria } \\
\text { e cosméticos }\end{array}$ & 0,3 & 0,4 & 0,6 & 1,4 & 0,3 & 0,6 & 11,6 & 11,6 & 1,9 & 1,9 \\
\hline 554 & $\begin{array}{l}\text { Sabão e produtos } \\
\text { de limpeza }\end{array}$ & 0,6 & 0,6 & 1,6 & 2,3 & 0,9 & 1,0 & 11,6 & 11,1 & 3,3 & 3,1 \\
\hline 598 & $\begin{array}{l}\text { Produtos químicos } \\
\text { diversos }\end{array}$ & 0,5 & 0,3 & 0,6 & 0,6 & 1,2 & 1,6 & 18,7 & 17,5 & 10,5 & 10,9 \\
\hline 764 & $\begin{array}{l}\text { Equipamentos de } \\
\text { telecomunicações }\end{array}$ & 0,1 & 0,7 & 3,2 & 4,1 & 3,8 & 9,0 & 16,0 & 9,8 & 14,5 & 5,9 \\
\hline 776 & $\begin{array}{l}\text { Lâmpadas, tubos e } \\
\text { válvulas de cátodo }\end{array}$ & 0,1 & 0,1 & 1,0 & 1,3 & 11,1 & 6,2 & 16,9 & 11,5 & 21,6 & 21,2 \\
\hline 792 & Aeronaves & 0,7 & 2,6 & 0,4 & 0,3 & 0,5 & 0,3 & 42,0 & 38,5 & 1,2 & 1,3 \\
\hline 871 & $\begin{array}{l}\text { Instrumentos } \\
\text { de óptica }\end{array}$ & 0,0 & 0,0 & 0,2 & 0,2 & 8,8 & 7,8 & 14,9 & 10,7 & 27,9 & 16,6 \\
\hline 872 & $\begin{array}{l}\text { Instrumentos e } \\
\text { aparelhos de medicina }\end{array}$ & 0,2 & 0,2 & 3,0 & 5,5 & 0,4 & 0,5 & 26,8 & 23,7 & 7,6 & 4,2 \\
\hline 873 & $\begin{array}{l}\text { Medidores e } \\
\text { contadores }\end{array}$ & 1,3 & 0,9 & 3,9 & 6,9 & 0,4 & 0,6 & 15,1 & 13,6 & 12,7 & 7,6 \\
\hline 874 & $\begin{array}{l}\text { Instrumentos e } \\
\text { aparelhos de medição }\end{array}$ & 0,2 & 0,2 & 1,3 & 2,7 & 0,7 & 0,7 & 26,8 & 24,3 & 13,2 & 11,1 \\
\hline 881 & $\begin{array}{l}\text { Equipamentos } \\
\text { fotográficos }\end{array}$ & 0,0 & 0,0 & 1,2 & 2,1 & 1,7 & 0,8 & 9,3 & 7,0 & 37,0 & 26,3 \\
\hline 882 & Materiais fotográficos & 1,4 & 0,7 & 1,5 & 2,1 & 0,4 & 0,7 & 14,9 & 15,2 & 23,4 & 22,5 \\
\hline 884 & Fibras de óptica & 0,2 & 0,1 & 0,8 & 0,7 & 3,0 & 2,7 & 14,0 & 12,7 & 21,8 & 24,7 \\
\hline $\begin{array}{l}\text { Total } \\
\text { do su }\end{array}$ & $\begin{array}{l}\text { das exportações } \\
\text { lbgrupo }\end{array}$ & 0,3 & 0,6 & 1,3 & 1,8 & 3,8 & 3,8 & 19,4 & 15,6 & 12,4 & 8,1 \\
\hline
\end{tabular}

Fonte: elaboração própria, a partir de PC-TAS (1994-1998) e INTRACEN (2001-2005). 
TABELA 6

Market-share das exportações sobre total das exportações da amostra de países 1994-1998 e 2001-2005 - Brasil e países selecionados (em \%)

\begin{tabular}{|c|c|c|c|c|c|c|c|c|c|c|c|}
\hline \multirow[b]{2}{*}{ Cód. } & \multirow{2}{*}{$\begin{array}{l}\text { País } \\
\text { Tipologia Pavitt }\end{array}$} & \multicolumn{2}{|c|}{ Brasil } & \multicolumn{2}{|c|}{ México } & \multicolumn{2}{|c|}{ Coréia do Sul } & \multicolumn{2}{|c|}{ EUA } & \multicolumn{2}{|c|}{ Japão } \\
\hline & & 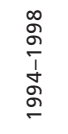 & $\begin{array}{l}n \\
\stackrel{\circ}{O} \\
\frac{1}{0} \\
\stackrel{0}{N}\end{array}$ & 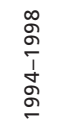 & 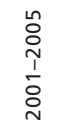 & 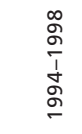 & 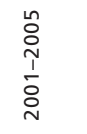 & 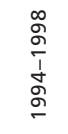 & 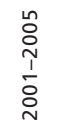 & 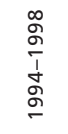 & 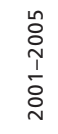 \\
\hline 110 & $\begin{array}{l}\text { Produtos primários } \\
\text { agrícolas }\end{array}$ & 13,5 & 21,4 & 7,4 & 8,6 & 2,7 & 1,8 & 75,1 & 66,4 & 1,4 & 1,8 \\
\hline 120 & $\begin{array}{l}\text { Produtos primários } \\
\text { minerais }\end{array}$ & 25,5 & 33,0 & 6,9 & 6,0 & 3,1 & 2,3 & 60,5 & 52,6 & 3,9 & 6,1 \\
\hline 130 & $\begin{array}{l}\text { Produtos primários } \\
\text { energéticos }\end{array}$ & 0,1 & 8,3 & 62,6 & 71,1 & 0,6 & 0,4 & 34,3 & 18,9 & 2,4 & 1,3 \\
\hline 211 & $\begin{array}{l}\text { Indústria } \\
\text { agroalimentar }\end{array}$ & 17,5 & 19,4 & 6,8 & 10,7 & 3,2 & 3,3 & 68,1 & 63,2 & 4,5 & 3,4 \\
\hline 212 & $\begin{array}{l}\text { Indústria intensiva } \\
\text { em outros recursos } \\
\text { agrícolas }\end{array}$ & 15,3 & 20,3 & 4,1 & 3,5 & 7,2 & 8,9 & 65,1 & 56,1 & 8,4 & 11,2 \\
\hline 213 & $\begin{array}{l}\text { Indústria intensiva em } \\
\text { recursos minerais }\end{array}$ & 5,1 & 5,0 & 4,6 & 4,2 & 14,4 & 14,6 & 50,4 & 49,0 & 25,6 & 27,1 \\
\hline 214 & $\begin{array}{l}\text { Indústria intensiva em } \\
\text { recursos energéticos }\end{array}$ & 3,4 & 9,6 & 4,2 & 10,2 & 24,1 & 30,0 & 54,4 & 37,5 & 13,9 & 12,7 \\
\hline 221 & $\begin{array}{l}\text { Indústria intensiva } \\
\text { em trabalho }\end{array}$ & 4,0 & 4,2 & 9,6 & 13,5 & 21,9 & 16,5 & 44,8 & 48,5 & 19,6 & 17,3 \\
\hline 222 & $\begin{array}{l}\text { Indústria intensiva } \\
\text { em escala }\end{array}$ & 3,2 & 3,7 & 8,8 & 12,2 & 11,1 & 13,1 & 31,4 & 28,6 & 45,5 & 42,4 \\
\hline 223 & $\begin{array}{l}\text { Fornecedores } \\
\text { especializados }\end{array}$ & 1,6 & 2,0 & 6,8 & 12,1 & 4,9 & 9,1 & 45,3 & 41,4 & 41,4 & 35,3 \\
\hline 224 & $\begin{array}{l}\text { Indústria intensiva } \\
\text { em } P \& D\end{array}$ & 0,9 & 2,0 & 3,6 & 6,1 & 10,3 & 13,0 & 52,1 & 51,8 & 33,1 & 27,1 \\
\hline
\end{tabular}

Fonte: elaboração própria, a partir de PC-TAS (1994-1998) e INTRACEN (2001-2005).

México se destacou, particularmente, no setor de "óleos e petróleo cru”). Ao lado dos EUA, o Japão aparece em segundo lugar, com os valores de marketshare em patamar menor (à exceção da indústria intensiva em escala), e seu desempenho se destaca nos setores mais intensivos em tecnologia, além da indústria intensiva em escala, também os subgrupos fornecedores especializados e a indústria intensiva em $P \& D$. 
A despeito das mudanças que foram observadas quanto a uma redução da importância dos países desenvolvidos no comércio internacional, viu-se que a parcela de mercado pertencente aos países em desenvolvimento é bastante inferior, além disso, o Brasil se destaca nos setores de exportação de primários, conformando um padrão de especialização comercial baseado fortemente em vantagens comparativas.

Pode-se concluir, a partir da classificação dos setores segundo a tipologia Pavitt, que, em primeiro lugar, os paises em desenvolvimento da América Latina, no caso Brasil e México, possuem uma estrutura de exportações distante e assimétrica em relação às experiências recentes da Coréia do Sul, EUA e Japão, pois a maior proporção das exportações encontra-se concentrada em indústrias de baixo conteúdo tecnológico. No caso do Brasil, os resultados encontrados corroboram estudos recentes de comércio exterior, ${ }^{6}$ que, utilizando a metodologia da UNCTAD para classificação das exportações segundo a intensidade tecnológica, mostraram a baixa participação das exportações brasileiras em produtos de alta intensidade tecnológica vis-à-vis a elevada concentração das exportações em commodities primárias, com destaque para ligeira melhora observada em 2005.

Em segundo lugar, o México apresentou um desempenho das exportações superior ao desempenho do Brasil em função de suas maquiladoras e integração com o mercado norte-americano, com uma participação das exportaçôes no período $2001-2005$ de $67 \%(31,5 \%+23,3 \%+12,0 \%)$ nas indústrias intensiva em escala, fornecedores especializados e intensiva em $P \& D$, contra apenas $38 \%(21,4 \%+8,5 \%+8,7 \%)$ do Brasil no mesmo período.

Em terceiro lugar, EUA, Japão e Coréia do Sul possuem uma estrutura de exportações fortemente concentrada em indústrias de maior conteúdo tecnológico. No período 2001-2005, a participação das exportaçóes na indústria intensiva em escala, fornecedores especializados e intensiva em P\&D foi de $72 \%$ na Coréia do Sul, 64\% nos EUA e 83\% no Japão.

Em quarto lugar, a análise setorial desagregada das exportações da indústria intensiva em $\mathrm{P} \& \mathrm{D}$ demonstrou que o setor "equipamentos de telecomunicações" apresentou forte oscilação ao longo do período 1994-2005: Brasil, México e Coréia do Sul aumentaram a participação das exportações nesse setor de aproximadamente 18 pontos percentuais, 5 p.p. e 33 p.p., 6 De Negri (2005) e IEDI (2006). 
respectivamente, enquanto EUA e Japão tiveram diminuição de participação de 1 p.p. e 5 p.p., respectivamente, no mesmo período. Outra mudança que se mostrou relevante ocorreu nas exportações do setor de "aeronaves", em que, no caso do Brasil, ocorreu um aumento da participação das exportações, passando de $28,75 \%$ para $43 \%$, enquanto os EUA perderam participação, passando de $27,61 \%$ para $24,69 \%$.

\section{Considerações finais}

A prescrição da literatura acerca da existência de uma relativa estabilidade entre os padrōes de especialização das exportações, em função das assimetrias tecnológicas entre países e das assimetrias intersetoriais dentro um mesmo país, parece confirmar-se em relação às exportações da induistria intensiva em $P \& D$ nas experiências latino-americanas do Brasil e México, os quais permanecem com uma composição das exportações ainda distante das experiências dos países desenvolvidos.

Por outro lado, a Coréia do Sul logrou a obtenção de um desempenho exportador similar aos países desenvolvidos, superando inclusive o Japão quanto à participação das exportações na indústria intensiva em P\&D. Tal desempenho, contudo, parece não se generalizar para o conjunto dos países em desenvolvimento.

A análise setorial da experiência recente brasileira da indústria intensiva em $P \& D$ revelou que as oportunidades de inserção externa virtuosa para exportações nessa indústria estão localizadas em alguns poucos setores, como é o caso do setor "aeronaves" e do setor "equipamentos de telecomunicações”, que apresentaram crescimento significativo das exportações no período recente, chegando a superar o desempenho dos países desenvolvidos. Portanto, as possibilidades de alterar a composição setorial das exportações brasileiras em direção aos setores de alta tecnologia, conformando um padrão de especialização comercial baseado em produtos dinâmicos do mercado mundial, continuam bastante restritas, limitando os efeitos benéficos de uma especialização comercial intensiva em tecnologia (capacidade de difusão para outros setores da economia, capacidade de responder mais rapidamente às mudanças nas condiçôes internacionais, elevadas barreiras à entrada etc.) sobre o crescimento e desenvolvimento econômico. 


\section{Referências bibliográficas}

Além, A.C.D. de. "Abertura comercial e financeira no México nos anos 80 e 90: principais resultados", Texto para Discussão, n.46, BNDES, 1996.

Amable, R.; Boyer, R. "L'Europe est-elle en retard d'un modèle technologique?", Économie Internationale, n.56, p.61-89, 1993.

Bell, M.; Pavitt, K. "Technological accumulation and industrial growth: contrasts between developed and developing countries", Industrial and Corporate Change, Brighton, v.2, n.2, p.157-209, 1993.

Canuto, O. "Mudança técnica e concorrência: um arcabouço evolucionista", Texto para Discussão, n.6, Campinas, UNICAMP, 1992.

Brasil e Coréia do Sul: os (des) caminhos da industrialização tardia, São Paulo: Nobel, 1994.

"Competition and endogenous technological change: an evolutionary model”, Revista Brasileira de Economia, 49 (1), p.21-33, jan.-mar., 1995.

Capdvielle, M.; Cimoli, M.; Dutrenit, G. "Specialization and technology in México: a virtual pattern of development and competitiveness?", Nota di Lavoro, n.96.09, Università cà Foscari di Veneza, 1996.

CIMOLI. "Technological gaps and institucional asymmetries in a North-Sul model with a continuum of goods", Metroeconomica, v.39, n.3, p.245-274, 1988.

De Negri, F. "Conteúdo tecnológico do comércio exterior brasileiro: o papel das empresas estrangeiras”, Texto para Discussão, n.1.074, IPEA, mar., 2005.

Dornbusch, R.; Fischer, S.; Samuelson, P. "Comparative advantage trade and payments in a ricardian model with a continuum of goods", American Economic Review, v.67, p.823-839, 1977.

Dosi, G. "The nature of the innovative process", in Dosi, G. et al., Technical change and economic theory, Nova York: Printer Publisch, 1988.

Technical change and industrial transformation: the theory and an application to the semicondutor industry, Londres: Macmilan Press, 1984. 
Dosi, G.; Pavitt, K.; Soete, L. The economics of technological change and international trade, Brighton: Wheatshaf, 1990.

Dowrick, S. "Innovation and growth: implications of the new theory and evidence", in Fagerberg, J.; Lundberg, L.; Hansson, P.; Melchior, A. (orgs.), Technology and international trade, Cheltenham: Edward Elgar, 1997.

Fajnzylber, F. La industrialización trunca de América Latina. México: Nueva Imagem, 1983 .

Ferreira Jr., H.M. “Globalização com integração regionalizada: México (1982-1992)”, Texto para Discussão, n.27, IESP, 1995.

Freeman, C. et al. "Chemical process plant: innovation and the world market", National Institute Economic Review, n.45, 1968.

Technology policy and economic performance: lessons from Japan, Londres: Pinter, 1987.

Gonçalves, R.; Baumann, R.; Prado, L.C.D.; Canuto, O. A nova economia internacional, São Paulo: Campus, 1998.

Guerrieri, P. "International trade pattern, structural change and technology in major Latin América countries", Giornali Degli Economisti e Annali di Economia, v.LIII, n.4-6, abr.-jun., 1994.

Holland, M.; Xavier, C.L. "Dinâmica e competitividade das exportações brasileiras: uma análise de painel para o período recente”, XXXII Encontro Nacional de Economia - ANPEC, 2004.

IEDI - Instituto de Estudos para o Desenvolvimento Industrial. "O Comércio Exterior Brasileiro em 2005”, mar., 2006. Disponível em <http:// www.iedi. org.br>. Acesso em julho de 2007.

INTRACEN - International Trade Centre. UNCTAD/WTO, 2006. Disponível em <http://www.intracen.org>. Acesso em outubro de 2006.

Krugman, P. "A model of innovation, technology transfer, and the world distribution of income", Journal of Political Economy, v.87, n.2, p.253-266, 1979. 
"Industrial organization and international trade", in Schmalensee, R.; Willig, R. (orgs.), Handbook of Industrial Organization, v.II, North-Holland: Elsevier Science Publishers, 1989.

Lall, S. Export performance, technological upgrading and foreign direct investment strategies in the Asian newly industrializing economies, Chile: CEPAL, 2000.

Laplane, M.F.; Sarti, F.; Hiratuka, C.; Sabbatini, R.C. "O caso brasileiro", in Chudnovsky, D. (coord.), El boom de las inversiones extranjeras directas en el Mercosur, Buenos Aires: Siglo XXI, 2001.

Laursen, K.; Meliciani, V. “The importance of technology based inter-sectoral linkages for market share dynamics", DRUID Working Paper, n.99-10, 1999.

Mani, S. Exports of high technology products from developing countries: is it real or a statistical artifact, INTECH, 2000. Disponível em <http:// www.intech. unu.edu>.

Moreno-Brid, J.C.; Rivas Valdivia, J.C.; Santamaría, J. "Mexico: Economic growth exports and industrial performance after NAFTA", Serie Estudios y Perspectivas, 42, CEPAL, Economic Development Unit, México, 2005.

Pavitt, K. "Sectoral patterns of technical change: towards a taxonomy and a theory", Research Policy, v.13, 1984.

PC-TAS - Personal Computer Trade Analysis System. International Trade Centre. UNCTAD/WTO, 1994-1998.

Posner, M.V. "International trade and technical change", Oxford Economic Papers, 13, p.323-341, 1961.

Santos Filho, O.C.; Ferreira Jr., H.M. "Coréia do Sul e Taiwan: aspectos históricosestruturais e de política industrial”, in Suzigan, W. et al., Reestruturação industrial e competitividade internacional, São Paulo: Fundação SEADE, 1989.

Tigre, P. "O papel da política tecnológica na promoção das exportações", in Pinheiro, A.C. et al., Desafio das exportaçôes, Rio de Janeiro: BNDES, 2002.

UNCTAD - United Nations Conference on Trade and Development. World investment report, 1995. 
World investment report, 1996.

Trade and development report, 2002.

Vernon, R. "International investment and international trade in the product cycle", Quarterly Journal of Economics, v.80, p.190-207, maio, 1966.

ENDEREÇOS PARA CORRESPONDENCIA:

Clésio Lourenço Xavier - clesio@ie.ufu.br

Ana Paula Macedo Avellar - anaavellar@ie.ufu.br

Samantha Ferreira e Cunha-cunhasf@yahoo.com.br

Instituto de Economia-Universidade Federal de Uberlândia

Campus Santa Mônica, bloco J, sala $1 \mathrm{~J} 239$

Avenida João Naves de Ávila, 2.121

CEP 38400-902

Uberlândia (MG)

Fone: (34) 3239-4167 